\title{
Correction to: Antioxidant and antibacterial activities of Artemisia absinthium and Citrus paradisi extracts repress viability of aggressive liver cancer cell line
}

\author{
Muhammad Ali $^{1}$ @ $\cdot$ Rida Iqbal $^{1} \cdot$ Muhammad Safdar $^{1} \cdot$ Sehrish Murtaza ${ }^{2} \cdot$ Ghulam Mustafa $^{3} \cdot$ Muhammad Sajjad $^{1}$. \\ Shazia Anwer Bukhari ${ }^{3}$. Tayyaba Huma ${ }^{1}$
}

Published online: 2 January 2022

(c) Springer Nature B.V. 2021

\section{Correction to: \\ Molecular Biology Reports (2021) 48:7703-7710 \\ https://doi.org/10.1007/s11033-021-06777-0}

The original version of this article unfortunately contained a mistake in one of the co-author name Dr. Ghulam Mustafa. During production process, his name was wrongly processed. The author name is corrected with this correction.

The original article has been corrected.

Publisher's Note Springer Nature remains neutral with regard to jurisdictional claims in published maps and institutional affiliations.
The original article can be found online at https://doi.org/10.1007/ s11033-021-06777-0.

Muhammad Ali

mali@akhuwatfirst.edu.pk

Rida Iqbal

ridaiqbal848@gmail.com

Muhammad Safdar

maliksafdar2331@gmail.com

Sehrish Murtaza

rph.sehrishmurtaza@gmail.com

Ghulam Mustafa

drghulammustafa@gcuf.edu.pk

Muhammad Sajjad

saqisajjad824@gmail.com
Shazia Anwer Bukhari

bukhari.shazia@yahoo.com

Tayyaba Huma

tayyabashahbaz@gmail.com

1 Department of Biotechnology, Akhuwat Faisalabad Institute of Research Science and Technology (A-FIRST), 38000 Faisalabad, Pakistan

2 Institute of Pharmacy, Physiology, and Pharmacology, Faculty of Veterinary Science, University of Agriculture Faisalabad (UAF), 38000 Faisalabad, Pakistan

3 Department of Biochemistry, Government College University Faisalabad (GCUF), Faisalabad, Pakistan 